\title{
Historical Geography of Vanga-Samatața and Harikela
}

\begin{abstract}
Abhijit Datta*
ABSTRACT

The eastern part of Indian sub-continent is known as Bengal. It carried different names in different times indicating the whole of Bengal. On the other hand, since ancient times to pre-Mughal period Bengal was divided into different geographical divisions. These are called as Puṇụravardhana, Vārendra, Gauḍa, Rāḍha, Suhma, Tāmralipta, Vañga, Vāngalā, Samtatața, Harikela. These divisions overlapped with each other in different times. In 1947, the eastern part of Bengal was merged with Pakistan and the western part included in Indian union. The division of Vanga-Samatata and Harikela formed a separate entity in eastern side of Bengal, which is situated now in Bangladesh. It played an important role in the social, economic and cultural life of Bengal. Located on the seashore it easily maintained a trade relation with the outside world through the overseas route in the period of feudal system in Bengal.
\end{abstract}

Key words: Vañga-Samatața-Harikela, Aitareya Āranyaka, Gañge, Janapada, Nāvya,

*Assistant Professor, Islampur College, PO-Islampur, Dt-Uttar Dinajpur, India 


\section{Introduction}

The land of Bengal has historically had a distinct 'regional entity'. The land is considered as a definite 'geographical region' in the entire sub-continent with distinct geo-features. ${ }^{1}$ Bengal is the name given to the eastern part of the Indian subcontinent, which formed a single province of British India. It extended up to the Himālayas in the north and the Bay of Bengal in the south. Its eastern and western limits were Brahmaputra, the Kanggsā, the Surmā, the Sajjuk rivers and the Nāgar, the Barākar and lower reaches of Suvarṇarekhā respectively. ${ }^{2}$ The above area was located roughly between $27^{\circ} 9^{1}$ and $20^{\circ} 50^{1}$ north latitude and $86^{\circ} 35^{1}$ and $92^{\circ} 30^{1}$ east longitude. ${ }^{3}$ There were deep forests, highlands and mountains in the east, west and north, and the Bay of Bengal in the South. This way these natural girdles surrounded Bengal. As Niharranjan Roy rightly puts, "At one extreme are the very high mountains, at the other the sea, and on both sides the hard hilly country, within, all the land is a plain. Such is the geographical fortune of the Bengali people." 4

In the early period of Indian history, the region of Bengal covered a large territorial area including the modern state of West Bengal and some parts of the adjoining districts of Assam and Bihar and included the parts of present day of Bangladesh. In Assam the area included under the provinces of Bengal were Goalpara, Sylhet and Cachar. The districts of Mānbhūm, Sāntāl Parganas and Pūrṇea of Bihār, also formed the part of the territory of Bengal. The Sarkārs of Sylhet and Purnea, the Pargana of Akmahal (now Rājmahal) and the famous pass of Teliagarhi, now in Santal Parganas, formed the integral parts of the subah of Bengal in the days of Akbar. ${ }^{5}$

The internal area of Bengal mostly depended on its river system, which formed the most characteristic physical feature of the land. Satish Chandra precisely states that as we have veins and arteries in our body, Bengal is also vivified by its numerous

1 Spate, O.H.K, \& A. T. A.Learmonth \& B.H. Farmer., India, Pakistan \& Ceylon: 'The Bengal Delta'(Region-XII),London, Methuen \& Co. Ltd.,3 ${ }^{\text {rd }}$ Edition Revised \& completely reset,1967,pp-571-599;Morgan,J.P \& W.G. McIntire., 'Quaternary Geology of the Bengal Basin, East Pakistan \& India', Bulletin of the Geographical Society of America,Vol.LXX,1959,pp-319-342;Rashid,Haroun. Er., East Pakistan, A Systematic Regional Geography \& it Development Planning Aspects, Sh. Ghulam Ali \& Sons,1965; Abdul Momin Chowdhury, 'Bānglār Bhaugolik Porichay' in Bangia Sāhityer Itihās, edited by Anisuzzaman, in Bangla, Dhaka: Bangia Academy, 1987, pp. 1-48

2 Majumdar, R. C, (ed.), The History of Bengal, Vol. I, Hindu Period, University of Dacca,Dacca,1943, p-1;Mukherjee, R., and Maity, S.K., 'Introduction', Corpus of Bengal Inscriptions, Calcutta, Jadavpur University,1967,p-1

3 Majumdar, R. C,(ed.), opcit, p-1

4 Hood, John ,W.,(tr.) History of the Bengali People(From Earliest Times to the Fall of the Sena Dynasty), Translated from original Bengali Bāngālir Itihās of N.R.Roy, Kolkata, Orient Blackswan,1994,p-53

$5 \quad$ Ibid,p-52 
rivers. ${ }^{6}$ N.R. Roy also mentions that the course of history of Bengal has largely been dictated by its numerous and diverse rivers and streams. These waterways have developed as the life force of the country through the ages. They have determined its appearance and nature, as they continue to do still. ${ }^{7}$ These waterways, however, have sometimes been a boon to Bengal and sometimes a curse. Since time immemorial, they played a very important role in the formation of deltaic land, which, in turn, molded the nature and character of human inhabitants. Amongst all the rivers that drenched the region, Brahmaputra was the greatest stream, stretching approximately 1800 miles. ${ }^{8}$ The second largest river was the Ganges, over 1200 miles long in the delta. Other rivers included Bhagirathi, Padmā, Meghnā, Surmā , Ichhāmati, the Mathābhānga and the Garai, the Betnā, the Rupsā, the Kumār, the Bhairab , Ajay, Damodar, Kansāi or Kapisa, Dvārakeśhvar, Rupnārāyan, Tistā, Torșā, Karatoyā, Âtrāi, Punarbhara, Koushikī(the modern Kośhī)and more. These all rivers repeatedly have changed their courses over the centuries. The process of destruction and reconstruction is still active. ${ }^{9}$ M.H. Rashid comments that it was indeed the tangled network of these rivers and their countless branches that formulated this geographical entity. ${ }^{10}$ Unfortunately, most of above mentioned rivers have disappeared in modern Bengal. Apart from rivers, canals, streams, bils, haors also formed significant elements of the historical geography of Bengal. ${ }^{11}$ The total area of the region of Bengal is approximately 80,000 sq. miles $(2,07,000 \mathrm{sq}$ $\mathrm{km}) .{ }^{12}$ Nafis Ahmed and M. Harunur Rashid are of the opinion that the area should be extended to 84,832 sq. miles $(30,691$ sq. miles in West Bengal and 54,141 sq. miles of present Bangladesh. ${ }^{13}$ Two other prominent researchers like B.M. Morrison and Abdul Momin Chowdhury have indicated the extension of territory as 80,000 sq. miles on the basis of Spate, Bagchi and Strickland. Therefore, it is too tough to verify the exact geographical area of Bengal.

6 Mitra Satish Chandra , Yashohar- Khulnār Itihās(in Bengali),Calcutta, Chakravarti, Chatterji \& Co,1922,p-12

7 Hood,John, W,(tr.).,opcit,P-53

8 Morrison, B.M., Political Centres and Cultural Regions of Early Bengal, Tucson, University of Arizona Press,1970,Reprint:Jaipur-Delhi,Rawat Publications,1980,P-10

9 Hood,John,W.,(tr.),opcit,P-56

10 Rashid, M.Harunur, "The Geographical Background to the History and Archaeology of South East Bengal', Journal Asiatic Society Bengal,Vol.XXIV-VI,1979-81,p-164

11 Chakrabarti, Dilip Kumar., Ancient Bangladesh - A Study of the Archaeological Sources, Oxford University Press, Delhi, 1992,p-20 ; Rashid,M.Harnur.,opcit,p-170

12 Spate, O.H.K., A.T.A. Learmonth., and B.H. Farmer., India, Pakistan and Ceylon: The Regions,pp-571-72;Bagchi,K.,The Ganges Delta, Chapers-1-3, Calcutta, University of Calcutta,1944 ;Strichland, C., Deltaic Formation with special reference to the Hydrographic Processes of the Ganges and the Brahmaputra, Calcutta, Langsmans, Green,1940,p-8

13 Ahmed, Nafis, An Economic Geography of East Pakistan, London, Oxford University Press,1958,P-2;Rashid M. Harunur, opcit, P-160 
The different areas of what was known as Bengal in pre-partition days carried different geographical designations in ancient times. It is, therefore, very difficult to ascertain anything definite about the geography and local areas of ancient Bengal. It can be said that in ancient Bengal and present day, the natural boundary of an area was usually the river, whose beds changed constantly ${ }^{14}$ and the area adjoining the river changed its geographical boundaries accordingly. The difficulty is further enhanced by the rise and fall of the political circumstances also. It can be clarified from an example that Tāmralipti (modern Tamluk) was included in Vanga and Kotivarșha(Modern Dinājpur) is mentioned as the chief city of Rāọha since early period of the zenith of Vanga and Rădha. However, in the era of the Pālas and the Senas, there were two general and broad geographical divisions: Gauda and Vanga. These were the two broad politico-geographical divisions of the ancient and medieval era, and can be roughly identified with West and Eastern Bengal respectively. From the $12^{\text {th }}$ and $13^{\text {th }}$ centuries, onwards Gauda and Vanga gradually became interchangeable terms owing to their political unification under the same sovereign, styled both Vangapati and Gaudeśvara, and the process was completed in the Mughal and British periods. Thus, the other geographical names of Bengal in olden days included Pundravardhana and Varendrī (North Bengal),Suhma(Hooghly district),Rādha (the Birbhum-Bankura-Hooghly-Howrah and portions of Medinipur districts, thus including at times the ancient Suhma region),Tāmralipti or Tāmralipta (modern Tamluk in the Medinipur district )and Dandabhūkti (Danton and its adjoining regions in the Medinipur district, sometimes including northern portions of Orissa),Vanga (traditionally located in the central deltaic Bengal, i.e. Dhaka, Vikrampur, Faridpur areas of present Bangladesh),Samatața(comprising Chittagong, Comilla and Noakhali districts of present day of Bangladesh), Harikela (Comilla, Śrīhațta and Chittagong districts of Bangladesh),Chandradvīpa(Barisal district of present Bangladesh)and Vāngalā(Chittagong, Noakhali and Barisal districts of present Bangladesh). These names have come to us from ancient epigraphic and literary records. The detailed analysis of the relevant information shows that they were geographically associated with Gauda or Vanga, that is, Western and Eastern Bengal. No two of them are mutually exclusive. In other words, some geographical boundaries are known to have overlapped and not remained restricted in the same region, and have assumed different names in different historical period. Thus, it is proven that the well-known area has shifted boundaries time to time, assuming a new shape and a new name each time.

The province of Bengal is given its present name by the British, and this name does not find in ancient and medieval literature. Therefore, the question that naturally comes to our mind is how Bengal received its present name. In Bengali, the term employed in modern times to denote the province is Bānglā, of which the English rendering is Bengal. The term 'Bānglā' or 'Bāngālā' is derived from 'Vanga' which is

14 Paul, P.L., The Early History of Bengal, Vol. I , Calcutta, The Indian Research Institute, 1939, p-1 
so frequently used in early and medieval Indian epigraphy and literature. The English have adapted it into their own language as 'Bengal'. Before the partition of India in 1947, 'Bengal' or 'Bānglā' was, introduce as the name of the province of Bengal in British India. Due to the division, the area was divided between the provinces of West Bengal and East Pakistan. In 1971 CE, East Pakistan region became the Republic of Bangladesh. The word 'Bānglā' or Bengal is still in use in the areas of West Bengal (India) and Bangladesh. However, these conditions are largely at a private level aimed at strengthening the cultural unity between West Bengal and the people of Bangladesh. These names have been culturally consolidated and kept alive in West Bengal, Bengali speaking areas of Bangladesh and adjacent areas. Two terms, phonetically akin to Bengal or Bāngālā occur in epigraphic and literary documents of the ancient and medieval periods. They are Vanga and Vāngalā. The famous historian Abul Fazl in his Äin-i-Akbarī made the following remark, "The original name of Bengal was 'Bang'. Its former rulers raised mounds measuring ten yards in height and twenty in breadth throughout the province, which were called ' $a l$ '. From this suffix, the name Bengal took its rise and currency."15 Under Akbar's rule, the entire area from Chittagong to Teliagarhi pass was known as 'Subāh Bāngalāh'. Sources of still earlier periods refer to a tract known as Vāngālā. Its existence as a geographical entity can be traced from the 8th century CE onwards. But epigraphic and literary references to Vāngalā amply bear testimony to its existence territorially distinct from a region called Vanga. Marco Polo describes Bānglā as a province in the south, its people speaking a strange language and being 'wretched idol worshipers'. It is further describe as 'a favorable stop for India'.16 According to Yule, Marco Polo's Bāngālā was the Pegu. However, this note may also apply to the Noākhāli-Chittagong-Tippara region of southeastern Bengal. It is corroborated by the account of Ovington. It runs, "Āracan is bounded by the kingdom of the Bay of Bengal, some authors making Chatigam its first border city". ${ }^{17}$ It is thus clear that the subāh of Bāngalāh during Akbar's paramountcy time marks the entire area, which was equivalent to the undivided province of Bengal. Bengal is referrer as the Bengal country by Ralph Fitch, and denotes the same Region. However, the term Vāngalā is use in a restricted sense. If Abul Fazl is to be believe, the term Vāngalā is derive from the word Vanga. Thus from the above discussion we may conclude that Bāngalā came from the word 'Banga'. It includes the entire Bengali-speaking area of the eastern part of the Indian sub-continent. Though in early period of history 'Banga' denoted a part of Bengal, that is, south-eastern

15 Jarett, H.S.,(tr.) , Āin-i-Ākbarī of Ābul Fazl, Vol. II, Calcutta, Asiatic Society of Bengal, 1894,p-120

16 Yule, Henry,(tr. \& ed.),The Book of Ser Mārco Polo, Vol. II, London, John Murray, 1873, Chap.LV,pp-97,98 and p-80

17 Ovington John, $A$ Voyage to Suratt, In the Year 1689,London, Jacob Tonfan,1696, pp-55354

Chatgaon has been described as 'a big city in the sea and a wooden belt' in Ain-i-Akbari. Jarett, H.S., (tr.),Opcit,p-125 
Bengal, after the assumption of power by the British the term 'Vanga' or 'Bāngalā' converted to 'Bengal' linguistically.

\section{Vanga-Samatața-Harikela}

From the pre-historic time to the Medieval Age Bengal was divided into different janapadas like Gauḍa, Puṇ̣ra, Varendra, Rāḍha, Sumha, Tāmralipta, Samatața, Vanga, Vānglā etc, as already mentioned before. These janapadas did not emerge as a power at the same time. In different courses of time, a certain portion of the entire area emerged as a supreme power and it extended its territory over a large area. Sometimes it included the other powerful states mentioned above within its territory. These janapadas had separate existence. It was during the time of Gaudadhipa Saśānika in the eight-century CE and afterwards that the janapadas of Pundira, Gauḍa and Vanga became identical with the whole of Bengal. Apart from the existence of different janapadas new divisions of Bengal like Vāngalā, Harikela, Chandradwipa, and Samatata emerged and they had further sub-divisions.18 Gradually, however, those sub-subdivisions ceased to exist. There was an endeavour to integrate the different areas in the name of Gauda from the period of Śaśannka to the rise of the Pālas, but it proved to have been a failure. ${ }^{19}$ The whole of Bengal assuming the name of Vanga emerged in the Muslim period. The culmination was reached during the time of Akbar when the Subāh of Bengal came into prominence. Bengal came into existence with more complete form during the time of British. Although it was cut to size from, what it was during the time of Akbar. From the $4^{\text {th }}$ century CE onwards, the chronological periods are satisfactorily datable based on epigraphically records. These help us to trace more clearly the chief political or geographical divisions and administrative units of Bengal. Therefore, at the present state of our knowledge, it would perhaps be appropriate to enumerate the more important divisions along with short explanatory notes on the various connotations of the names gleaned from epigraphic and literary sources.

Vanga was an ancient janapada or human settlement in the history of Eastern Bengal of history. ${ }^{20}$ This unit was mainly restricted to Dhaka-Faridpur-Munshiganj and Barisal areas of present Bangladesh. B.N. Mukherjee suggests an area covering the modern districts of 24-Parganas (both north and south),Hoogli, Howrah and Medinipur and parts of Burdwan (and also of Birbhum, Bankura and Nadia).He also incorporates the coastal region of present Bangladesh up to the mouth of the Padma

18 Roy N.R., Bāngāleer Itihās: Āadi Parba, Kolkata, Dey Publishing,1959(BS),pp-108

19 ibid; Majumdar, R.C.,(ed.). opcit,p-77

20 Pargiter, F.E, "Ancient countries in Eastern India”, Journal of the Asiatic Society of Bengal, Vol. LXVI, Part-I, 1897,p-85;Saha, Radharaman, Pābnā Zillār Itihasa,VolI,Pabna,1330(BS), Dey's Publishing Edition, Kolkata,2004(Reprinted),p-1 
during the first three or four centuries CE. ${ }^{21}$ Geographically, it is composed of the Ganges Delta. The rivers like Bhagirathi, Padma and Meghna surround the unit and its boundaries have changed from time to time.

The name Vanga, indicating a people and a state, is mentione for the first time in Aitareya Âranyaka. ${ }^{22}$ Here, they are represented as a group of people who were associated with Magadhas. Vangas have been mentioned in the Baudhāyana Dharmasūtra ${ }^{23}$ as a group of people who lived in areas outside the Aryan civilization. In the Purānas, along with Vangas there are other people, such as Anga, Magadha, Mudgaraka, Puṇ̣ra, Videha, Tāmralipta and Prāgjyyotisa. The earliest reference to Vanga as a territorial unit is find in the Arthaśāstra. Here we find an area famous for and enriched with white and soft cotton fabrics. ${ }^{24}$ The references in the Mahāniddesha( $2^{\text {nd }}$ century CE) and in the Milindpanho(c $1^{\text {st }}$ or $2^{\text {nd }}$ Century CE) indicate that there was a coastal area approachable from the sea in the territory of Vanga Some indication of its location and its political power can also be collected from Kālidāsa's Raghuvamiśa, as Raghu, the hero of Raghuvamiśa came to Vanga after defeating Sumha. Then he set up a pillar to mark the victory in the islands situated between the channels of the Ganges where people fought in their boats. ${ }^{25}$ Therefore, the story indicates that the location of Vanga is on the eastern side of the Hooghly branch of the Bhagirathi. Whereas the Sumha lived on the other side. Meherauli Inscription of Chandra indicates that the King Chandra extirpated his enemies from the Vanga country in battle. ${ }^{26}$ According to Yasodhara, a commentator on the Kämasūtra of Vātsyayana, Vañga lies to the east of the Lauhitya (the Brahmaputra). ${ }^{27}$ Thus, it may be inferred that the location of Vanga is in the triangular deltaic land between the two main streams of the Ganges-the Bhagirathi

21 Mukherjee, B.N., Post-Gupta Coinages of Bengal, Calcutta, Coins Study Circle,1989,p1;Banga Bāngalā O Bharat(in Bengali),Progressive Publishers,Kolkata,2000,pp-3-8; 'Kharoști and Kharoști-Brāhmi Inscriptions in West Bengal (India)',Indian Museum Bulletin, Vol. XXV, Calcutta, Indian Museum,1990,Appendix III (The earliest Limits of Vanga)

22 Keith, A.B., (ed.\& tr.), The Aitareya Aranyaka, Oxford, The Clarendon Press, 1909,p-200

23 Olivelle, Patrick., (ed. \& tr.), Dharmasūtras: The Law Codes of Apastamba Gautama, Baudhāyana \& Vaśiștha, Motilal Banarsidass, New Delhi,2000,p-198

24 Shamasastry, R.,(tr.),opcit,pp-83-84; Cf. Bhattacharyya, Amitabha, opcit, p-58.It is mentioned as Vangakam śvetam-snigdhans-dūkulam.

25 Devadhar, C.R.,(ed.),Raghuvamiśa of Kālidāsa,Chapter-4,Verse-36,Delhi, Motilal Banarsidass, 1985

26 Sharma, G.R., 'Chandra of the Mehrauli Pillar Inscription', The Indian Historical Quarterly, Vol.XXI, 1945, 202-212; Sircar, D.C., 'Meharauli Iron Pillar Inscription of Chandra',pp275-277; Fleet, J.F., 'Meharauli Iron Pillar Inscription of Chandra', Corpus Inscriptionum Indicarum, Vol. III, Calcutta, 1888, p-141; Agarwal, Ashvini., Rise and Fall of Imperial Guptas, New Delhi, Vedic Book,1989,pp-177-18

27 Goswami Damodar Shastri,(ed.) Kāmasūtra of Vātsayana, Benaras, Jaikrishnadas and Haridas Gupta , 1929, pp. 294-95 
and the Padma. This was probably termed by the Classical Greek and Latin writers as Gangāridai or Gañge. The inhabitants of this area naturally were well known for their naval power. ${ }^{28}$ The Chinese text Wei-luch ( $3^{\text {rd }}$ Century CE) referred to PanYech, i.e., Vanga, as the country of Han-yuch (Xan-gywat) or the Ganga. ${ }^{29}$ Periplus and Ptolemy mention Chandraketugarh as a riverine port situated on the bank of the river Vidyādhari (once an important tributary of the Bhagirathi) resembles 'Gañge'. Ranabir Chakravarti designates Chandraketugarh as a riverine port having facilities of both coastal long distance high-sea voyages..$^{30}$ Brajadulal Chattopadhyaya suggested Chandraketugarh as one of the important early historical urban centres and ports of lower deltaic Bengal. ${ }^{31}$

According to the Great Epic,32 the sage Dirghatamas and Sudeșna, queen of Bali gave birth to five sons who were named Anga, Vanga, Kalinga, Pundra, Suhma and the land conquered by them came to be known after their names. This story is imprecisely supported by the Purānas. Among them, Vanga, Pundra and Sumha formed three important principalities over Bengal's territorial area in the early stage. ${ }^{33}$ This story attests to the fact that the kingdom of Vanga as a janapada existed in the Epic period extending roughly from $4^{\text {th }}$ century B.C. to $4^{\text {th }}$ century AD. ${ }^{34}$ The story of Dirghatamas also indicates that in ancient India, Rishis and saints used to take an active role in spreading the Aryan civilization to remote areas. ${ }^{35}$

In the Meherauli Iron Pillar Inscription of King Chandra, ${ }^{36}$ around the $5^{\text {th }}$ century CE Vanga has been mentioned for the first time as a janapada. The name of Vanga used as Vāngalādeśam in the Tirumālāi Rock Inscription of Rājendra Chola, dated 1025 CE. ${ }^{37}$ Like the other janapadas, with the change of power, the regional jurisdiction of

28 Majumdar, R.C., opcit, p-2

29 Cf. Mukherjee, B.N., 'Coastal and Overseas Trade in Pre-Gupta Vanga and Kalinga', Trade in Early India, ed. By Ranabir Chakravarti, Oxford India Paperbucks, New Delhi,2005,p199-200

30 Chakravarti, Ranabir, Trade and Traders in Early Indian Society, Manohar,Delhi,2002,pp129-130

31 Chattopadhyaya, Brajadulal, Studying Early India: Archaeology, Texts and Historical Issues, Permanent Black,Delhi,2003,pp-76-78

32 Mahābhārata, Ādi Parva,Ch-CIV,52-55; Harivamía, Harivamśa-parva, Ch. XXXI,33-42

33 Sen, B.C., Some Historical Aspects of the Inscriptions of Bengal,(thesis), Calcutta, University of Calcutta,1942,p-2;Sen, Sukumar , Vãngalā Sāhityer Itihāsa, Vol.I,5 ${ }^{\text {th }}$ Edition, Calcutta, Ananda Publishers1970,p-12

34 Chakravarti Rajanikanta, Gauḍer Itihāsa,Vol.I,Calcutta,1317(BS),Reprint Dey's Publishers,Kolkata,1999,p-2

35 Pargiter, F.E., 'Ancient Countries in Eastern India', Journal of the Asiatic Society of Bengal ,Vol.LXVI,Part-I,1897,Calcutta,PP-29-36

36 Sharma, G.R., 'Meharauli Iron Pillar Inscription of King Chandra', The Indian Historical Quarterly, Vol. XXI, 1945,pp- 202-212

37 Hultzsch E, 'Tirumālāi Rock Inscription of Rājendra Chola', p-231 
Bengal expanded at times beyond its boundaries or contacted within its boundaries. Therefore, it is a very difficult task to demarcate the exact boundary of any janapada like Vanga in the ancient period. However, the available sources help us to hypothesize that at least in the $12^{\text {th }}$ century CE, Vanga (in some accounts 'Bang' or Bāngālāh) generally related to the eastern and southern Bengal, ${ }^{38}$ lying on the western side of the Bhagirahi including Chittagong and Dacca Division. ${ }^{39}$

The epigraphical sources reveal that there were two sub-divisions of Vanga named 'Vikramapura-bhāga' and 'Nāvya-bhāga'.40 In the later Pala period, we find Vañga divided into two parts: northern and southern (Anuttara).The Kāmāuli Copper plate of Vaidyadeva distinctly refers to Anuttara-Vanga or southern Vanga.41 It implies sharply the existence of Uttara-vanga (Northern Vanga). It has been suggested that Ganga served as the boundary between north and southern Vanga. The two divisions of Vanga implied in Vaidyadeva's Grant might have identical to the two bhägas of the same territory mentioned in the later Sena inscriptions, namely the Vikramapura-bhāga and Nāvya. ${ }^{42}$ King Vallalsena (c 1058-117 CE) divided his territory of Bengal into five principalities or divisions. The divisions are Rădha, Bāgdi, Vanga, Varendra and Mithila ${ }^{43}$ Thus, the fact that revealed is that during Sena period Vanga assimilated within the Sena Kingdom, but it existed as a separate administrative unit.

Vanga witnessed the rise of an independent kingdom with $6^{\text {th }}$ century. Gopachandra (525-540 CE),Dharmāditya (540-560 CE) and Samāchārdeva (560 CE) were powerful rulers of this unit. They issued seven copper plates, which suggest the territory extended over an area from Baleswar in Orissa, through the southern part

38 Raverty, H.G., (ed. \& tr. ), opcit,p-557 ; Sen. B.C, Some Historical Aspects of the Inscriptions of Bengal, p-2;Majumdar,R.C., 'Lāmā Tārānāth's Accounts of Bengal', The Indian Historical Quarterly, Vol. XIV,No-2,1940,p-227-235

39 Rahim, Abdur, Social and Cultural History of Bengal, Vol. I, Karachi, 1963, p-2; Law, B.C., 'The 'Vangas', Indian Culture, Vol. I,1934-35,p-57-63

40 Sircar, D.C., 'Madanapāḍa Plate of Viśvarupasena, Epigraphia Indica, Vol. XXXIII,1960,pp315-326; 'Madanapādā Plate of Viśvarupasena', Journal of the Asiatic Society Letters, Vol. XX, 1954,p-209-219;Majumdar, N.G., 'Madanapāḍā Copper-plate of Viśvarupasena', pp-133-140; 'Calcutta Sāhitya-Parishat Copper-plate of Viśvarupasena',p-141; 'Translation of Calcutta Sāhitya-Parishat Copper-plate of Viśvarupasena', pp-177-78,180

41 Venis Arthur, 'Copper plate Grant of Vaidyadeva, King of Kāmarupa', Epigraphia Indica,Vol.II,1892,p-349;Maitreya Akshaya Kumar, Gauḍa-Lekha-Mãlā (in Bengali),Rajshahi, Varendra Research Musuem,1319(BS),p-140

42 Venis, Arthur, 'Copper-plate Grant of Vaidyadeva, King of Kāmrupa', Epigraphia Indica,Vol.2,No-28,pp-347-358

43 Lethbridge. E, An Easy Introduction to the History and Geography of Bengal, London, Macmillan \& Co,1881, Calcutta,1875(Reprinted),p-13;Chakravarti,Rajanikanta, opcit,p164 ;Blochman,H.,Contribution to the Geography and History of Bengal, Calcutta, Asiatic Society,1968,p-63 
of West Bengal (Vardhanamāna bhukti) to the southern part of Bangladesh (Navyāvakāśsikā and Varakamaṇuala). These include three copper plates from Jayarāmapura, Mallasarul and Faridpur issued by Gopachandra, two Faridpur copper plates issued by Dharmāditya and two-named Kurpala and Ghugrahati copper plates issued by Samāchārdeva. ${ }^{44}$ From the $10^{\text {th }}$ to the middle of $13^{\text {th }}$ century, Vanga was under the rule of the Chandras, the Varmans, and finally the Senas.

From the above discussion, it is very difficult to ascertain the exact location of Vanga in different periods of history because its territorial areas changed from time to time. However, it extended in a vast area, but in the Sena period, the territorial jurisdiction of Vanga had contracted, and on the eve of Muslim invasion, the name Vanga was in vogue denoting a small portion of Bengal. However, it gradually extended its territorial jurisdiction and ultimately assumed as a country with the name of Bengal.

Another territorial unit sometimes considered identical with Vanga, named Vāngalā, was a well-known division of ancient Bengal. The unit phonetically similar to Vanga, denotes South-Eastern Bengal in general. In tracing its location and relation with Vanga the term 'Vāngalā' may be discussed with special attention. It might have had a separate existence at a certain period of time. Vanga no doubt is older than Vāngalā and it can be traced back to the Epic Age. ${ }^{45} \mathrm{Dr}$. H. C. Roychowdhury is of the opinion that 'Vanga' and 'Vāngalā' are two separate countries and he suggests that Vāngalā was probably identical with Chandradvipa. ${ }^{46}$ Several inscriptions of south India and the Tārikh-i-Firuzshāhi ${ }^{47}$ mention Vanga and Vāngalā separately. ${ }^{48}$ On the other hand, P.L. Paul states that Vanga and Vāngalā cannot be counted as two separate countries. ${ }^{49}$ Vāngalā is probably thought to be an etymological variation of Vanga, possibly made by southerners and foreigners. ${ }^{50}$ We do not find any mention of Vāngalā before $10^{\text {th }}$ century CE.

44 Pargiter, F.E., 'Three Copper-plate Grants from East Bengal', Indian Antiquary, Vol. XXXIX,1910, pp-193-216; Bhattasali, N.K., 'The Ghugrāhāti Copper-plate Inscription Samāchāradeva', Epigraphia Indica, Vol. XVIII, 1925-26, pp-74-86; Cf. Chakrabarti, Amita, opcit,pp-20-37; Cf. Jahan Shahnaj Husne, Excavating Waves and Winds of Exchange-A study of Maritime Trade in Early Bengal, Joha and Erica edges Ltd., Oxford, British Archaeological Reports, 2006,pp-31-34

45 Mahabharata, Ädi Parva,pp-113-114

46 Ray Chaudhury, Hemchandra, "Vañga Kon Deśa", in Mānasi-O-Marmavani,(1336 B.S),1929, pp-566-587ff

47 Elliot and Dowson,(eds.), opcit, Vol. III, 1871, London, Trubner \& Co., p-295

48 Fleet, J.F., 'Inscriptions at Āblur', Epigraphia Indica, Vol. V, 1898-99, p-257

49 Paul, P. L., 'Vaṅga and Vāngalā', Indian Historical Quarterly,Vol.XII,1936,p-522-24

50 Paul, P. L, opcit, Vol. I p-V 
Originally, Vāngalā denoted the coastal areas of south-eastern Bengal.51 Thus, the territory overlapped with the Nāvya sub-division of Vanga. This area may be coextensive with Chandradvipa (present Barishal division in Bangladesh).This was the stronghold of the Chandras before the expansion of their rule to the whole of Vanga. Thus, it gradually superseded Vanga in ordinary use and emerged as a country comprising all the previous janapadas or divisions in its jurisdiction in subsequent times. Thus Vanga proper was now included in the new kingdom of Vāngalā. As a result of this, the name Vāngalā could be optionally used in an expanded sense to indicate a large area in East Bengal that formed part of the kingdom of Śrīchandra (belongs to Chandra dynasty) and his successors. By this time, Vanga and Vāngalā apparently signified more or less the same territory. ${ }^{52}$

The earliest reference to Vāngalā is find in the Nesari plates (805 CE) of the Rāștrakūta King Govinda III. It speaks of Dharmapāla as the king of Vāngalā53. The name is often use in records and works later than $10^{\text {th }}$ century. The Tirumālāi Inscription (1025 CE) of Rājendra Chola speaks of King Govinda Chandra of Chandra dynasty as the Lord of Vānglādeśa.54 In the Āblur Inscription, Vanga and Vāngalā have been mentioned as two separate countries. ${ }^{55}$ Lama Tārānāth, a great Tibetan Buddhist monk used the term Bhāngalā instead of Vāngalā to differentiate from Rāḍha and Varendra. ${ }^{56}$ After a vivid observation Ābul Fazl comments, Bāngāl's (Vāngalā) original name was Bang (Vanga).Its former rulers raised hillock. It was ten yards in height and twenty yards in breadth, throughout the province. These were called $a l$. The name of Bāngāl might have come from this suffix. ${ }^{57}$

It is recorded in the Raghuvamśa that the Vanga people were defeated in the land watered by the lower streams of the Ganges. ${ }^{58}$ From the epigraphic references, it is reveal that Vanga comprised the Vikramapura region of Dacca and Faridpur ${ }^{5}$ and the Nāvya region most probably the Faridpur and Buckergunge districts. ${ }^{60}$ Thus, it indicates that Vanga certainly includes at least the part of present Dacca, Faridpur

51 Sircar, D.C., opcit,p-132; Bhattacharyya, A., opcit,pp-62-64

52 Sircar ,D.C., opcit,p-134

53 'Nesari Plate of Govinda III', Journal of Asiatic Society (Letters),Calcutta,Vol.XXII,P-133134,1956

54 Hultzsch, E., 'Tirumālāi Rock Inscription of Rājendra Chola I',opcit,p233;Chakrabarti,Amita,opcit,p-14-15

55 Fleet, J.F., 'Inscriptions at Āblur', Epigraphia Indica,Vol.V,1898-99,p-213-265

56 Majumdar, R.C., 'Lāmā Tārānāth's Account of Bengal', Indian Historical Quarterly,Vol.XVI,1940-41, p-226;Chattopadhyaya,Annapurna,The people and Culture of Bengal-A study in Origin, Vol-1,Part-2,Kolkata,Firma KLM Pvt. Ltd.2002,pp-389-395

57 Cf. Sircar,D.C.,opcit,p-132-140; Cf. Sircar, 'Origin of the name Bengal', Indian Historical Quarterly, Vol. XXIII,1947,p-63

58 Raghuvamsa,IV,36

59 Majumdar, N.G., 'Edilpur Copper-plate of Keśavasena',p-125

60 ibid 
and Buckergunge districts. ${ }^{61}$ Thus, it is clear that the southern part of the Vanga region became, known for the first time as Vāngalā, as known from many references. In course of time, the region became a separate identity as Vāngalā.

European writers of the $16^{\text {th }}$ and the $17^{\text {th }}$ centuries mentioned a city of Bengala near the Meghna estuary i.e. the confluence of the Padma and the Meghna. This estuary extends over the wide area between the districts of Buckergunge and Chittagong in East Pakistan. Here Bengala is evidently a foreign corruption of Vāngalā. R.C. Majumdar, in this connection, has suggested that this late medieval city of Bengala which was situated near modern Chittagong was the capital of the ancient Vāngalādeśa. The city of Bengala was also famous having for its seaport.62

Thus, the above discussion shows that the two words 'Vanga' and 'Vāngalā' are indiscriminately used in various sources. Sometimes both are mentioned together. Most probably, the term Vāngalā first became popular in South India. From the references of the South Indian inscription, it can be seen that the word 'Vāngalā' used to refer to a part of Vanga and does not refer to a separate unit of Vanga. In this connection, D.C. Sircar stated that the Chandras of South-East Bengal are sometimes represented as lords of Chandra-dvipa and sometimes as lords of Vāngalā-deśa. The connotation of the name began to expand with the expansion of the Chandra Kingdom of Vāngalā over wide areas of South-east Bengal.

Samatata is another ancient regional unit of Southeast Bengal, whose name is not ethnic, but descriptive. Since Samudragupta's time the unit had a distinct identity and was well-known and well-recognised. It is located at mouth of the Brahmaputra River (near Comilla) in the south-east of Bengal. It includes the areas of Noakhali, Comilla, Chittagang and adjacent areas in present Bangladesh and some parts of present Tripura in India. Geographically it was a low-land constituted by delta and flood plains made by the activities of the rivers Surma and Meghna. It was on the surface of Trippera, with the low hill range of Lālmāi as its eastern end.63 Cunningham is of the opinion of that Samatata is to be identified with the delta of the Ganges including the Sunderbans between the Huranghata river and Bukerganj ${ }^{64}$.He further added Samatata is a place covering 200 or 217 miles to the south of Kamrupa and 150 miles to the east of Tāmralipti65.

61 Sircar.D.C.,opcit,p-133

62 Majumdar, R.C., 'Lāma Tārānātha's Accounts of Bengal', pp-227-235

63 Rashid, M.Harunur, 'The Geographical Background to the History and Archaeology of South-East Bengal', Journal of Asiatic Society of Bengal, Vol.XXIV-VI,1979-81,p-169-177

64 Cunninghum, A., Ancient Geography of India, the Buddhist period including the Campaigns of Alexander and the Travels of Hwan-Thsang,London,1871(first published),Low Price Publications,Reprinted,2006,pp-501-503

65 ibid,pp-423-424 
In the Allahabad Pillar Inscription of Samudragupta Samatata is mention as a frontier state along with Dāvaka, Kāmarupa, Nepala and Karttrpora. ${ }^{66}$ Varāhamihir who lived in the beginning of the $6^{\text {th }}$ century CE also mentions Samatata as geographical unit. 67 The Chinese pilgrim named Hiuen-Tsang, who visited India in the $7^{\text {th }}$ century, described it a low and moist sea-side as area with Buddhist monasteries. He mentions that he reached Samatata after a southward journey of 1200 or 1300 li from Kāmrupa and that the country was more than 3000 li(about $800 \mathrm{kms}$ ) in circuit. ${ }^{68} \mathrm{He}$ indicates that the land was a Buddhist centre. Based on the statement of Hiuen-Tsang, it is said that Samatata was bounded on one side by the sea. It arrives at the conclusion that 'the districts of 24Parganas, Khulna, Buckerganj etc, standing near the sea, were incorporated into Samatata'.69

Further information for the location of Samatata is provided by I-tsing, who mentions the king Rājbhața ruling over Samatața. This king is identified with Rājarājabhațta of the Khaḍga Dynasty, mentioned in Áśhrafpur Copper plate. ${ }^{70}$ The king ruled from the capital of Karmānta-Vāsaka. Based on above sources M. Harunur Rashid suggested that Karmānta-Vāsaka was the second capital of Samatața. ${ }^{71}$ The capital is identical with modern Baḍkamtā in the district of Tipperah (present Tripura), situated twelve miles west of Comilla. ${ }^{72}$ The fact testifies that Samatata extended up to Tipperah ${ }^{73}$ (present Tripura). Further information is corroborated by Baghaura and Nārāyanpur Image Inscriptions of the reign of Mahipāla I and the Mehar Copper-plate of Damodaradeva. ${ }^{74}$ It indicates also Vilikandhaka in Samatata.

66 Princep, James., 'Interpretation of the most Ancient of the Inscriptions $\mathrm{n}$ the Columns of Allahabad', Journal of Asiatic Society of Bengal, Vol. VI, Part-II, 1837,p-973; Princep, James., 'Note on Inscription on the Allahabad Column, Journal of Asiatic Society of Bengal, Vol.3, 1834,pp= 114-123;Cf. Chakrabarti, Dilip Kumar, opcit, pp. 24-25; Cf. Bhattacharyya, Amitabha, opcit, p- 65

67 Kern, J.H.K., (ed.), opcit,XIV,6

68 Watters, Thomas, On Yuan Chwang's Travels in India, eds. Davids T. Rhys\& Bushell,S, London, Royal Asiatic Society,1904 ,pp-187-188

69 Sen,B.C.,opcit, p-92

70 Laskar, G.M., 'Āsrafpur Copper-plate Grants of Devakhaḍga', Memoirs of Asiatic Society of Bengal, Vol. I, No-6, 1904-07, pp-85-91; Zakariah, A.K.M, 'Inscription', MaināmatiDevaparvata, Dacca, Asiatic Society of Bangladesh,1997, pp-210-211

71 Rashid, M. Harunur, 'Site and Surroundings', Maināmati- Devaparvata, ed. By A.B.M Hussain, Asiatic Society of Bangladesh,Dhaka,1997,p-8-12

72 Bhattasali, N.K., 'Some Image Inscriptions from East Bengal', Epigraphia Indica, Vol. XVII,1923-24, P-351; Bhattasali,N.K., 'A Forgotten Kingdom of East Bengal', Journal of Asiatic Society of Bengal, New Series, Vol.X.1914, p-87

73 Bhattacharyya Amitabha, opcit, pp. 66-67; Majumdar, R.C.,(ed.), opcit,p-17 Chakrabarti, Amita, opcit, pp. 16-18.

74 Sircar, D.C., 'Nārāyanpur Vināyaka Image Inscription of King Mahipāla, Regnal Year 4', Indian Culture, Vol. IX, 1942-43,pp- 121-25; Barua, B.M., and P.V. Chakravarti, 'Mehar Plate of Dāmodaradeva', Epigraphia Indica, Vol. XXVII,1947-48, pp-51-58; Sircar, D.C., 'Mehar Plate of Dāmodaradeva', Epigraphia Indica, Vol. XXX, 1987,pp-51-58 
It has been identified with the present village of Bilakindhuai in the Tippera district. The Kailan Copper plate of Śridharana Rāta also refers to Devaparvata as the headquarter of Samatața, ${ }^{75}$ now styled sārvatobhadraka(square or rectangleshaped), encircled by the river Kșīrodā like a moat. Elephants played in its water banks were adorned by cluster of boats. ${ }^{76}$

Samatata was founded after the fall of the Mauryan Empire, sometime after the death of Asoka in 232 BCE. Thereafter Samudragupta, around 335 C.E., incorporated it into the Gupta Empire. After the fall of the Gupta dynasty, political unrest arose in North India and in Bengal. Depending on scope of situation, some small dynasties ruled here, sometimes independently and sometimes under someone else's control. Not much is known about the kingdom's history. However, it is known that Buddhist kings ruled it in $7^{\text {th }}$ century A.D. Thus we find here five capitals of Samatata in five different consecutive phases of history, namely Kripura ${ }^{77}$, Vikrampura ${ }^{78}$, KarmāntaVāsaka ${ }^{79}$,Devaparvata ${ }^{80}$, Pațtikera ${ }^{81}$.

\section{Harikela}

Another geographical unit in ancient Bengal that existed in the tracts of South-East Bengal is Harikela or Harikeli or Holikola. There is a controversy among the scholars on the issue of the exact location of the area. Some scholars locate the division as a neighbour of the Samatața and identify it with Śrīhatța or Śrīhațadeśa now known as Sylhet. ${ }^{82}$ After careful observation, Adhir Chakravarti identifies it with Noakhali, Comilla, parts of Tippera and Chittagong districts, but not extended up to Śrīhațta, at

75 Sircar, D.C., 'The Kailān Copper-plate of King Śrīdharana Rata of Samatața Regnal Year 4', The Indian Historical Quarterly, Vol. XXIII,1947,pp-221-241; Sircar, D.C., ShilālekhaTāmraśhāsonadir Prasañga, (in Bangia), Kolkata, Sāhityalok,1982, pp. 65-74.

76 ibid; Chowdhury, Abdul Momin , Dynastic History of Bengal, Dacca, Asiatic Society of Pakistan,1967, p-146; Sircar, D.C., Select Inscriptions Bearing on Indian History and Civilization, Vol-2, Calcutta, University of Calcutta,1965, pp-36-40;

77 Alam, Aksadul, Deconstructing the 'Nationalist' construction of 'Indianisation' of Southeast Asia: Issues in Connectivity and Culture(up to CE-1300),Journal of the Asiatic Society of Bangladesh(Hum.),Vol.62(2),2017,p-143

78 Sircar, D. C., opcit,p-152-153

79 Rashid, M. Harunur, 'Site and Surroundings', Maināmati- Devaparvata, ed. By A.B.M. Hussain, Dhaka, Asiatic Society of Bangladesh,1997,pp-8-12

80 Zakariah, A.K.M., 'Inscriptions', Maināmati-Devaparvata,p-215

81 Rashid, M. Harunur., 'The city and its Environs',Mainamati-Devaparvata,pp-271-272

82 Sircar, D.C., 'Madanpur Plate of Śrīchandra, Year 46', Epigraphia Indica, Vol. XXVIII,1950,p-338; Basak, R.G., 'Madanpur Plate of Śrīchandra', Epigraphia Indica, Vol. XXVIII, 1950, pp-51-58; Sircar, D.C., 'Inscription of Bhavadeva', Journal of the Asiatic Society [Letters], Vol. XVII, 1951, pp. 89-90; Chowdhury, Abdul Momin, opcit, p-152. 
least not before the reign of Śīchandra. ${ }^{83}$ I-tsing, the $7^{\text {th }}$ century Chinese traveler, has defined its position as the eastern limit of the eastern India. ${ }^{84}$ The evidence of this information is supported by that of the Karpuramañjari of Rājśekhara ${ }^{85}$ written in $9^{\text {th }}$ century AD. It includes girls from Harikela among women of eastern Bengal. ${ }^{86}$ The most confusing statement appears in two late manuscripts now in the collection of Dhaka University Library named the Rudrakșa Māhātya ${ }^{87}$ and Rupachintāmanikośa.88 They take 'Harikela' as a synonym for Sylhet, without mentioning any source or evidence. This has created a lot of confusion. Another confusion comes from Hemachandra, the $12^{\text {th }}$ century lexicographer. He in his book, Abhidhanachintāmani equates Harikela with Vanga.89. This, however, has been contradicted in the Mañjuśrimmūlakalpa, ${ }^{90}$ where Harikela, Vanga, and Samatata are cited as separate units.

The most reliable document is supplied by an incomplete copper plate of Kāntideva who lived around $9^{\text {th }}$ century AD. It was discovered in an old temple in the Nāsirabad area of Chittagong. The source clearly points out that Kāntideva was the ruler of Harikela. ${ }^{91}$ But unfortunately no further information has been found from this source. The epigraphic source like the Rāmpāl Copper plate Inscription describes Trailokya Chandra belonging to Chandra dynasty of Eastern Bengal as the mainstay of the royal family of Harikela, ${ }^{92}$ who became the king of Chandradvipa

83 Chakravarti Adhir, 'Harikela's Contacts with Outside World', Journal of Ancient Indian History,Vol.XIX,Parts-1-2,1989-90,pp-2-3

84 Takakusu,J.,(tr.),A Record of the Buddhist Religion as Practiced in India and the Malay Archipelago(AD 671-695 )., Oxford, Clarendon Press,1896,2 ${ }^{\text {nd }}$ Indian Edition, Munshiram Manoharlal Publishers, New Delhi,1982,introduction,p-XXXIII,XLVI

85 Cf. Bhattacharya, D.C., 'Harikela and the Ruins at Maināmati', Historical Geography of India (Collection of Articles from the Indian Historical Quarterly)compiled by P.Mittal, \& Geeta Dua,Vol.2,Originals,Delhi,2005,p-396; Cf. Majumdar, R.C., opcit, p-17

86 Cf. Husain, Shahanara, Everyday Life in the Pala Empire, Dacca, Asiatic Society of Pakistan, 1968, p. 15.

87 Dhaka University Library Manuscript No-21,415

88 Dhaka University Library Manuscript No-1451

89 Cf. Mukherjee, B.N., 'The Original Territory of Harikela', Bangladesh Lalitkala, Vol.I, Part2, 1975, pp. 118-19. Hemachandra clearly mentioned Vngastu Harikeliyah i.e. 'the Vanga people have been Harikelised'; Cf. Chakravarti, Adhir, 'Harikela's Contacts with Outside World', p. 3

90 Ganapati, T., (ed.), Ārya-Mañjuśrī-Mūlakalpa , Sanskrit Series, No. LXX, Trivandrum, Bhaskara Press, 1920; Jayaswal, K.P., An Imperial History of India in a Sanskrit Text, With a special commentary on Later Gupta Period, Lahore: Motilal Banarsidass, 1934, pp. 68, 232-33

91 Majumdar, R.C., 'Chittagong Copper-plate of Kāntideva', Epigraphia Indica, Vol.XXVI,No45, 1941-42,pp. 313-318.

92 Basak, R.G., 'Rampal Copper Plate Grant of Śrīchandradeva', Epigraphia Indica,Vol.XII,No-18,1913-14,pp-136-142 
(Bakarganj district). Two other copper plate inscriptions of the Chandra ruler Śrīchandra (930-975 AD), namely Dhulla and Madanpur Copperplate inscriptions, also furnish the fact that the Chandras belonged to the landowners of Rohitagiri under the Kings of Harikela ${ }^{93}$. The above facts indicate that firstly Trailokyachandra inherited his feudatory position, gained more power and became the mainstay of the Harikela king.94 However, unfortunately the Chandra inscription does not provide any information needed for the location and identification of this kingdom. However, after careful analysis of the Chandra inscription and the conquests of the Chandras in Bengal, it can be clearly mentioned that this region was located in the Chittagong region of the Ārakān border. The discovery of Kāntideva's copper plate inscription supports this view. However, the view is also supported by reliable evidence furnished by Harikela coins discovered at Maināmati. It is strongly indicated by the discoveries that this Harikela was situated in the neighbourhood of Samatata and towards the direction of Ārakān. It includes about 400 coins, including 3 hoards consisting of 227 coins. ${ }^{95} \mathrm{~A}$ number of silver coins at Maināmati, which are palaeograplically to be place in the 7th-8th century AD,96 prove the existence of Harikela in the $7^{\text {th }}$ century AD. Further evidence has been provided by the discovery of the Jobra coin hoard in the very heart of Chittagong. These were 36 'Bull and Triglyph' type thin silver coins, 35 of them with 'Harikela' legend and one with the ancient Ârakān king 'Pritichandra' legend.

Though confusion prevails, it may be stated with sufficient information that Harikela was an important kingdom of Ancient Bengal. Of all such kingdoms in this area, Harikela has been the best for her contribution, but least documented. Possibly its situation in an obscure corner of the country is responsible for this neglect. It is a complicated matter that in Noakhali, Comilla used to be a part of both Samatata and Harikela. As a solution to the problem, it can be said that when a powerful dynasty emerged in these two regions, they were overlapped under that dynasty. Therefore, it may be concluded on the basis of these observations that Vanga, Samatata and Harikela were separate entities in ancient Bengal. However, in some places their identity presumably used to overlap due to their close proximity.

93 Sircar, D.C., 'Dhulla Plate of Śrīchandra', Epigraphia Indica, Vol.XXXIII,No-25,1959-60,pp134-140;Basak,R.G., 'Madanpur Plate Śríchandra ,Year 44',Epigraphia Indica,Vol.XXVIII,1949-50,pp-51-58;Sircar,D.C., 'Madanur Plate of Śrīchandra ,Year46',Epigraphia Indica,Vol-XXVIII,p-337-339

94 Chowdhury, Abdul, Momin., opcit, pp-158-62

95 Hossain, Md. Mosharraf, Maināmati-Lālmāi, Dibya Prakash,Dhaka,2006,pp-56-58

96 Mukherjee, B. N., Coins and Currency Systems in Gupta Bengal (AD 320-550),Harman Publishing House,Delhi,1992,pp-39-41 


\section{Conclusion}

Thus, from the above discussion, it is clear that the different areas of what was known as Bengal in pre-partition days carried different geographical designations in ancient times. The boundaries of these territorial divisions varied in different epochs of history owing to the rise and the fall of the political powers under which they were subjected. Gauda and Vanga were the principal among these and roughly denoted Western and Eastern Bengal. All these have come down to us from different epigraphical and literary records and a careful analysis of the relevant data would show that they were geographically connected with either Gauda or Vanga i.e. Western Bengal and Eastern Bengal. In other words, there was some geographical overlapping and not same region was sometimes denoted by different names in different historical epochs 
Jhss, Vol. 10, No. 1 , January to June, 2019

\section{References}

Abdul Momin Chowdhury, 'Bāñglār Bhaugolik Porichay' in Bañgia Sāhityer Itihās, edited by Anisuzzaman, in Bangla, Dhaka: Bangia Academy, 1987

Agarwal, Ashvini., Rise and Fall of Imperial Guptas, New Delhi, Vedic Book,1989

Ahmed, Nafis, An Economic Geography of East Pakistan, London, Oxford University Press, 1958

Alam, Aksadul, Deconstructing the 'Nationalist' construction of 'Indianisation' of South-east Asia: Issues in Connectivity and Culture(up to CE-1300),Journal of the Asiatic Society of Bangladesh(Hum.),Vol.62(2),2017

Banga Bāṅgalā O Bharat(in Bengali),Progressive Publishers,Kolkata,2000

Bhattasali, N.K., 'The Ghugrāhāti Copper-plate Inscription Samāchāradeva', Epigraphia Indica, Vol. XVIII, 1925-26, pp-74-86;

Bagchi,K.,The Ganges Delta, Chapers-1-3, Calcutta, University of Calcutta,1944

Barua, B.M., and P.V. Chakravarti, 'Mehar Plate of Dāmodaradeva', Epigraphia Indica, Vol. XXVII, 1947-48, pp-51-58

Basak,R.G., 'Madanpur Plate Śríchandra ,Year 44',Epigraphia Indica,Vol.XXVIII,194950

Basak, R.G., 'Rampal Copper Plate Grant of Śrīchandradeva', Epigraphia Indica,Vol.XII,No-18,1913-14

Bhattasali, N.K., 'Some Image Inscriptions from East Bengal', Epigraphia Indica, Vol. XVII, 1923

Bhattasali,N.K., 'A Forgotten Kingdom of East Bengal', Journal of Asiatic Society of Bengal, New Series, Vol.X.1914, p-87

Cf. Bhattacharya, D.C., 'Harikela and the Ruins at Maināmati', Historical Geography of India (Collection of Articles from the Indian Historical Quarterly)compiled by P.Mittal, \& Geeta Dua,Vol.2,Originals,Delhi,2005

Blochman,H.,Contribution to the Geography and History of Bengal, Calcutta, Asiatic Society 
Cf. Husain, Shahanara, Everyday Life in the Pala Empire, Dacca, Asiatic Society of Pakistan

Cf. Mukherjee, B.N., 'Coastal and Overseas Trade in Pre-Gupta Vanga and Kalinga', Trade in Early India, ed. By Ranabir Chakravarti, Oxford India Paperbucks, New Delhi,2005

'Calcutta Sāhitya-Parishat Copper-plate of Viśvarupasena' 'Translation of Calcutta Sāhitya-Parishat Copper-plate of Viśvarupasena'

Cf. Mukherjee, B.N., 'The Original Territory of Harikela', Bangladesh Lalitkala, Vol.I, Part-2, 1975

Cf. Sircar, 'Origin of the name Bengal', Indian Historical Quarterly, Vol. XXIII, 1947

Cf. Jahan Shahnaj Husne, Excavating Waves and Winds of Exchange-A study of Maritime Trade in Early Bengal, Joha and Erica edges Ltd., Oxford, British Archaeological Reports, 2006

Chakrabarti, Dilip Kumar., Ancient Bangladesh - A Study of the Archaeological Sources, Oxford University Press, Delhi, 1992

Chakravarti Adhir, 'Harikela's Contacts with Outside World', Journal of Ancient Indian History,Vol.XIX,Parts-1-2,1989-90

Chakravarti Rajanikanta, Gauḍer Itihāsa,Vol.I,Calcutta,1317(BS),Reprint Dey's Publishers,Kolkata,1999

Chakravarti, Ranabir, Trade and Traders in Early Indian Society, Manohar, Delhi,2002

Chattopadhyaya, Brajadulal, Studying Early India: Archaeology, Texts and Historical Issues, Permanent Black,Delhi,2003

Chattopadhyaya,Annapurna,The people and Culture of Bengal-A study in Origin, Vol1,Part-2,Kolkata,Firma KLM Pvt. Ltd.2002

Chowdhury, Abdul Momin , Dynastic History of Bengal, Dacca, Asiatic Society of Pakistan,1967

Cunninghum, A., Ancient Geography of India, the Buddhist period including the Campaigns of Alexander and the Travels of Hwan-Thsang,London,1871(first published),Low Price Publications,Reprinted,2006 
Jhss, Vol. 10, No. 1 , January to June, 2019

Devadhar, C.R., (ed.),Raghuvamiśa of Kālidāsa,Chapter-4,Verse-36,Delhi, Motilal Banarsidass, 1985

Dhaka University Library Manuscript No-1451

Dhaka University Library Manuscript No-21,415

Elliot and Dowson,(eds.), Vol. III, 1871, London, Trubner \& Co.

Fleet, J.F., 'Inscriptions at Āblur', Epigraphia Indica, Vol. V, 1898-99

Ganapati, T., (ed.), Ārya-Mañjuśrī-Mūlakalpa , Sanskrit Series, No. LXX, Trivandrum, Bhaskara Press, 1920

Jayaswal, K.P., An Imperial History of India in a Sanskrit Text, with a special commentary on Later Gupta Period, Lahore: Motilal Banarsidass, 1934

Goswami Damodar Shastri,(ed.) Kāmasūtra of Vātsayana, Benaras, Jaikrishnadas and Haridas Gupta , 1929

Hood, John ,W.,(tr.) History of the Bengali People(From Earliest Times to the Fall of the Sena Dynasty), Translated from original Bengali Bāngālir Itihās of N.R.Roy, Kolkata, Orient Blackswan,1994

Hossain, Md. Mosharraf, Maināmati-Lālmāi, Dibya Prakash,Dhaka,2006

Hultzsch E, 'Tirumālāi Rock Inscription of Rājendra Chola'

Jarett, H.S.,(tr.) , Āin-i-Ākbarī of Ābul Fazl, Vol. II, Calcutta, Asiatic Society of Bengal, 1894

'Kharoști and Kharoști-Brāhmi Inscriptions in West Bengal (India)',Indian Museum Bulletin, Vol. XXV, Calcutta, Indian Museum,1990,Appendix III (The earliest Limits of Vanga)

Keith, A.B., (ed.\& tr.), The Aitareya Aranyaka, Oxford, The Clarendon Press, 1909

Laskar, G.M., 'Āsrafpur Copper-plate Grants of Devakhaḍa', Memoirs of Asiatic Society of Bengal, Vol. I, No-6, 1904-07

Law, B.C., 'The 'Vangas', Indian Culture, Vol. I,1934-35

Lethbridge. E, An Easy Introduction to the History and Geography of Bengal, London, Macmillan \& Co,1881, Calcutta,1875(Reprinted) 
Madanapāḍā Plate of Viśvarupasena', Journal of the Asiatic Society Letters, Vol. XX, 1954

Mahābhārata, Ādi Parva,Ch-CIV,52-55; Harivaṁ́̇a, Harivamía-parva, Ch. XXXI

Maitreya Akshaya Kumar, Gauḍa-Lekha-Mālā (in Bengali),Rajshahi, Varendra Research Musuem,1319(BS)

Majumdar, N.G., 'Edilpur Copper-plate of Keśavasena'

Majumdar, N.G., 'Madanapāḍā Copper-plate of Viśvarupasena', pp-133-140;

Majumdar, R. C, (ed.),The History of Bengal, Vol. I, Hindu Period, University of Dacca,Dacca,1943

Majumdar, R.C., 'Lāmā Tārānāth's Account of Bengal', Indian Historical Quarterly,Vol.XVI,1940 -41

Majumdar, R.C., 'Chittagong Copper-plate of Kāntideva', Epigraphia Indica, Vol.XXVI,No-45, 1941-42

Mukherjee, R., and Maity, S.K., 'Introduction', Corpus of Bengal Inscriptions, Calcutta, Jadavpur University,1967

Mitra Satish Chandra , Yashohar- Khulnār Itihās(in Bengali),Calcutta, Chakravarti, Chatterji \& Co,1922

Morrison, B.M., Political Centres and Cultural Regions of Early Bengal, Tucson, University of Arizona Press,1970,Reprint:Jaipur-Delhi,Rawat Publications,1980

Morgan,J.P \& W.G. McIntire., 'Quaternary Geology of the Bengal Basin, East Pakistan \& India', Bulletin of the Geographical Society of America,Vol.LXX,1959

Mukherjee, B. N., Coins and Currency Systems in Gupta Bengal (AD 320-550),Harman Publishing House,Delhi,1992

Mukherjee, B.N., Post-Gupta Coinages of Bengal, Calcutta, Coins Study Circle,1989

Nesari Plate of Govinda III', Journal of Asiatic Society (Letters),Calcutta,Vol.XXII,1956

Olivelle, Patrick., (ed. \& tr.), Dharmasūtras: The Law Codes of Apastamba Gautama, Baudhāyana \& Vaśiștha, Motilal Banarsidass, New Delhi,2000

Ovington John, $A$ Voyage to Suratt, In the Year 1689,London, Jacob Tonfan,1696 
Pargiter, F.E, "Ancient countries in Eastern India", Journal of the Asiatic Society of Bengal, Vol. LXVI, Part-I, 1897

Pargiter, F.E., 'Three Copper-plate Grants from East Bengal', Indian Antiquary, Vol. XXXIX,1910

Paul, P. L., 'Vañga and Vāngalā', Indian Historical Quarterly,Vol.XII,1936

Paul, P.L., The Early History of Bengal, Vol. I , Calcutta, The Indian Research Institute, 1939

Principe James., 'Interpretation of the most Ancient of the Inscriptions $\mathrm{n}$ the Columns of Allahabad', Journal of Asiatic Society of Bengal, Vol. VI, Part-II, 1837

Principe, James., 'Note on Inscription on the Allahabad Column, Journal of Asiatic Society of Bengal, Vol.3, 1834

Ray Chaudhury, Hemchandra, "Vañga Kon Deśa", in Mānasi-O-Marmavani,(1336 B.S),1929

Roy N.R., Bānigāleer Itihās: Āadi Parba, Kolkata, Dey Publishing, 1959(BS)

Rahim, Abdur, Social and Cultural History of Bengal, Vol. I, Karachi, 196

Rashid, M. Harunur, 'Site and Surroundings', Maināmati- Devaparvata, ed. By A.B.M. Hussain, Dhaka, Asiatic Society of Bangladesh,1997

Rashid, M.Harunur, 'The Geographical Background to the History and Archaeology of South East Bengal', Journal Asiatic Society Bengal,Vol.XXIV-VI,1979-81

Rashid,Haroun. Er., East Pakistan, A Systematic Regional Geography \& it Development Planning Aspects, Sh. Ghulam Ali \& Sons,1965

Saha, Radharaman, Pābnā Zillār Itihasa,Vol-I,Pabna,1330(BS), Dey's Publishing Edition, Kolkata,2004

Sen, B.C., Some Historical Aspects of the Inscriptions of Bengal,(thesis), Calcutta, University of Calcutta, 1942

Sen, Sukumar , Vāngalā Sāhityer Itihāsa, Vol.I,5 ${ }^{\text {th }}$ Edition, Calcutta, Ananda Publishers, 1970 
Sharma, G.R., 'Chandra of the Mehrauli Pillar Inscription', The Indian Historical Quarterly, Vol.XXI, 1945

Sharma, G.R., 'Meharauli Iron Pillar Inscription of King Chandra', The Indian Historical Quarterly, Vol. XXI, 1945

Sircar, D.C., 'Dhulla Plate of Śrīchandra', Epigraphia Indica, Vol.XXXIII,No-25,1959-60

Sircar, D.C., 'Madanapāḍa Plate of Viśvarupasena, Epigraphia Indica, Vol. XXXIII,1960

Sircar, D.C., 'Madanpur Plate of Śrīchandra, Year 46', Epigraphia Indica, Vol. XXVIII,1950

Sircar, D.C., 'Mehar Plate of Dāmodaradeva', Epigraphia Indica, Vol. XXX, 1987, pp51-58

Sircar, D.C., 'Meharauli Iron Pillar Inscription of Chandra'; Fleet, J.F., 'Meharauli Iron Pillar Inscription of Chandra', Corpus Inscriptionum Indicarum, Vol. III, Calcutta, 1888

Sircar, D.C., 'Nārāyanpur Vināyaka Image Inscription of King Mahipāla, Regnal Year 4', Indian Culture, Vol. IX, 1942-43

Sircar, D.C., 'The Kailān Copper-plate of King Śrīdharana Rata of Samatața Regnal Year 4', The Indian Historical Quarterly, Vol. XXIII,1947

Sircar, D.C., 'Inscription of Bhavadeva', Journal of the Asiatic Society [Letters), Vol. XVII, 1951

Sircar, D.C., Select Inscriptions Bearing on Indian History and Civilization, Vol-2, Calcutta, University of Calcutta, 1965

Sircar, D.C., Shilālekha-Tāmraśhāsonadir Prasañga, (in Bangia), Kolkata, Sāhityalok, 1982

Spate, O.H.K, \& A. T. A.Learmonth \& B.H. Farmer., India, Pakistan \& Ceylon: 'The Bengal Delta'(Region-XII),London, Methuen \& Co. Ltd.,3rd Edition Revised \& completely reset,1967

Strichland, C., Deltaic Formation with special reference to the Hydrographic Processes of the Ganges and the Brahmaputra, Calcutta, Langsmans, Green,1940 
Jhss, Vol. 10, No. 1 , January to June, 2019

Takakusu,J.,(tr.),A Record of the Buddhist Religion as Practiced in India and the Malay Archipelago(AD 671-695 )., Oxford, Clarendon Press,1896,2nd Indian Edition, Munshiram Manoharlal Publishers, New Delhi,1982,introduction,p-XXXIII,XLVI

Venis Arthur, 'Copper plate Grant of Vaidyadeva, King of Kāmarupa', Epigraphia Indica,Vol.II,1892

Watters, Thomas, On Yuan Chwang's Travels in India, eds. Davids T. Rhys\& Bushell,S, London, Royal Asiatic Society,1904

Yule, Henry,(tr. \& ed.),The Book of Ser Mārco Polo, Vol. II, London, John Murray, 1873

Zakariah, A.K.M, 'Inscription', Maināmati-Devaparvata, Dacca, Asiatic Society of Bangladesh, 1997 